\title{
KEMAMPUAN MENGHITUNG INTEGRAL TAK TENTU DAN TENTU DARI FUNGSI ALJABAR SEDERHANA SERTA PENERAPANNYA DALAM MENGHITUNG LUAS DAERAH DI BAWAH KURVA SISWA KELAS XII IPS SMA SYAICHONA CHOLIL SAMARINDA TAHUN AJARAN 2017/2018
}

\author{
Panca Kristiana ${ }^{1),(*)}$ \\ P.M. Labulan ${ }^{1)}$ \\ Berahman $3^{2)}$ \\ 1), 2), 3) Program Studi Pendidikan Matematika, Universitas Mulawarman \\ ${ }^{(*)}$ Email: pancakristina@gmail.com
}

\begin{abstract}
ABSTRAK
Suatu penelitian deskriptif kuantitatif yang bertujuan untuk mengetahui kemampuan menghitung integral tak tentu dan tentu dari fungsi aljabar sederhana serta penerapannya dalam menghitung luas daerah di bawah kurva siswa kelas XII IPS SMA Syaichona Cholil Samarinda Tahun Ajaran 2017/2018. Penelitian ini dilakukan pada bulan Desember 2017, dengan subjek penelitian sebanyak 47 siswa, dan dengan objek penelitian yaitu kemampuan menghitung integral tak tentu dan tentu dari fungsi aljabar sederhana serta penerapannya dalam menghitung luas daerah di bawah kurva. Instrumen yang digunakan untuk mengumpulkan data dalam penelitian ini adalah tes tertulis berupa soal uraian sebanyak 6 butir soal. Teknik analisis data meliputi penilaian hasil tes kemampuan, pengelompokkan siswa berdasarkan nilai yang diperoleh, penyajian data dan penarikan kesimpulan. Hasil penelitian ini menunjukkan bahwa 2,13\% siswa berada dalam kategori sangat baik, 4,26\% siswa berada dalam kategori baik, 4,26\% siswa berada dalam kategori cukup, dan $89,36 \%$ siswa berada dalam kategori kurang. Dengan demikian kemampuan menghitung integral tak tentu dan tentu dari fungsi aljabar sederhana serta penerapannya dalam menghitung luas daerah di bawah kurva siswa kelas XII IPS SMA Syaichona Cholil Samarinda Tahun Ajaran 2017/2018 adalah kurang..
\end{abstract}

Kata kunci: Kemampuan menghitung, Integral, SMA Syaichona Cholil Samarinda.

\begin{abstract}
A quantitative descriptive research which aim to find out the calculate abilities of the indefinite integral and definite integral from simple algebra function with the application in calculate under curve area at student of class XII IPS SMA Syaichona Cholil Samarinda academic year 2017/2018. This research did on December 2017, with subject 47 students, and the object of this research is the calculate abilities of the indefinite integral and definite integral from simple algebra function with the application in calculate under curve area. The result of this research is test which consist 6 items. The result of this research that seen from entirety subject are 2,13\% student in very good
\end{abstract}

Kemampuan Menghitung Integral Tak Tentu Dan Tentu Dari Fungsi Aljabar Sederhana Serta Penerapannya 105 
ability category, 4,26\% student in good ability category, 4,26\% student in enough ability, and $89,36 \%$ student in the less ability category. So, the calculate abilities of the indefinite integral and definite integral from simple algebra function with the application in calculate under curve area at student of class XII IPS SMA Syaichona Cholil Samarinda academic year $2017 / 2018$ is less.

Keywords: Calculate ability, Integral, SMA Syaichona Cholil Samarinda.

\section{PENDAHULUAN}

Usaha untuk meningkatkan pembangunan sumber daya manusia melalui pendidikan perlu mendapat perhatian khusus. Hal tersebut sejalan dengan UU Sistem Pendidikan Nasional No. 20 tahun 2003 (UU Sisdiknas, 2003) yang menyatakan: Tujuan pendidikan nasional adalah mencerdaskan kehidupan bangsa dan mengembangkan manusia Indonesia seutuhnya yaitu manusia yang bertakwa terhadap Tuhan Yang Maha Esa dan berbudi pekerti luhur, memiliki pengetahuan dan keterampilan, kesehatan jasmani dan rohani, kepribadian yang mantab dan mandiri serta tanggung jawab kemasyarakatan dan kebangsaan.

Pengetahuan dan keterampilan yang dibangun tidak lepas dari minat yang dimiliki siswa untuk ikut serta dalam mengembangkan kemampuannya. Pengetahuan yang diharapkan dalam penelitian ini mengacu pada mata pelajaran matematika pada kemampuan menghitung.

Integral merupakan materi yang dipelajari di kelas XII. Integral memiliki karakteristik yang cukup abstrak dan di dalamnya terdapat banyak rumus sehingga dalam mempelajarinya dibutuhkan ketelitian, kecepatan dalam berfikir dan kemampuan menghitung yang baik. Umumnya materi integral diajarkan setelah siswa menyelesaikan materi prasyarat yaitu Limit dan Diferensial. Selain kedua materi tersebut, banyak materi lain yang juga merupakan dasar dan terkait langsung dengan operasi-operasi dalam integral. Materi tersebut antara lain aljabar, geometri dan trigonometri.

Sebagai dasar penulisan dalam penelitian ini, yaitu nilai rata-rata ulangan harian matematika materi pokok diferensial siswa kelas XI IPS di SMA Syaichona Cholil Samarinda tahun pelajaran 2016/2017. Rata-rata nilai untuk kelas XI-A adalah 58,25 sedangkan untuk kelas XI-B adalah 55,70. Dari uraian tersebut, terlihat bahwa nilai rata-rata ulangan harian yang dicapai oleh siswa masih berada di bawah KKM dengan nilai KKM adalah 75. Menanggapi hal tersebut peneliti melakukan wawancara dengan guru matematika pengampu kelas XII IPS SMA Syaichona Cholil Samarinda memberikan informasi bahwa, banyak siswa tidak dapat menyelesaikan soal matematika yang diberikan dengan baik dan benar, misalnya saja ketika siswa diberi soal latihan mereka hanya mampu menjawab soal-soal yang sama persis dengan contoh. Hal ini pun sering terjadi ketika soal-soal yang diberikan melibatkan operasi hitung yang sederhana. Lemahnya pemahaman konsep

106 Kemampuan Menghitung Integral Tak Tentu Dan Tentu Dari Fungsi Aljabar Sederhana Serta Penerapannya Dalam Menghitung Luas Daerah Di Bawah Kurva Siswa Kelas XII IPS SMA Syaichona Cholil Samarinda Tahun Ajaran 2017/2018

Panca Kristiana - P.M. Labulan - Berahman 
peserta didik pada materi-materi sebelumnya diduga sebagai pemicu adanya kesulitan untuk menyelesaikan soal yang melibatkan operasi hitung di materi berikutnya. Dengan menceritakan masalah yang ada, guru matematika di sekolah itu berharap penulis mengadakan penelitian mengenai masalah tersebut yang nantinya dapat membantu mencari solusi pemecahan permasalahan yang ada ketika siswa menghitung integral tak tentu dan tentu dari fungsi aljabar sederhana serta penerapannya dalam menghitung luas daerah di bawah kurva.

Pengertian secara psikologis Slameto (2012:2), belajar merupakan suatu proses perubahan yaitu perubahan tingkah laku sebagai hasil dari interaksi dengan lingkungannya dalam memenuhi kebutuhan hidupnya. Perubahanperubahan tersebut akan nyata dalam seluruh aspek tingkah laku. Jihad (2013:4) menyatakan belajar merupakan perbuatan yang terjadi karena interaksi seseorang dengan lingkungannya yang akan menghasilkan suatu perubahan tingkah laku pada berbagai aspek, diantaranya pengetahuan, sikap, dan keterampilan. Aunurrahman (2016:35), mengartikan belajar merupakan suatu proses yang dilakukan individu untuk memperoleh suatu perubahan tingkah laku yang baru secara keseluruhan, sebagai hasil pengalaman individu itu sendiri di dalam interaksi dengan lingkungannya.

Slameto (2003:3) mengemukakan bahwa hasil belajar adalah suatu proses usaha yang telah dicapai seseorang untuk mendapatkan suatu perubahan tingkah laku yang baru secara keseluruuhan sebagai suatu pengalaman seseorang tersebut dengan lingkungannya. Jihad (2013:15) hasil belajar adalah perubahan tingkah laku siswa secara nyata setelah dilakukan proses belajar mengajar yang sesuai dengan tujuan pengajaran. Dimyanti dan Mudjiono (2006:3) menyatakan bahwa hasil Belajar merupakan hasil dari suatu interaksi tindak belajar dan tindak mengajar. Dari sisi guru, tindak mengajar diakhiri dengan proses evaluasi hasil belajar. Dari siswa, hasil belajar merupakan berakhirnya penggal dan puncak proses belajar.

Kemampuan berasal dari kata "mampu". Menurut kamus besar bahasa Indonesia (2010:100) mampu adalah kuasa (bisa, sanggup) melakukan sesuatu. Kemampuan dapat diartikan kesanggupan, kekuatan, kebolehan yang dimiliki seseorang untuk melakukan sesuatu. Purwadarminta (1990:45), menyatakan bahwa kemampuan adalah kesanggupan, kecakapan dalam melakukan sesuatu, baik berupa tindakan atau perubahan, mampu berupa tutur kata. Lebih lanjut Munandar (1995: 44), menyatakan bahwa kemampuan adalah merupakan daya untuk melakukan suatu tindakan sebagai hasil dari pembawaan dan latihan.

\section{METODE PENELITIAN}

Jenis penelitian ini merupakan penelitian deskriptif kuantitatif dengan tujuan untuk menggambarkan secara kuantitatif tentang kemampuan menghitung integral tak tentu dan tentu dari fungsi aljabar sederhana serta penerapannya dalam menghitung luas daerah di bawah kurva siswa kelas XII 
IPS SMA Syaichona Cholil Samarinda tahun ajaran 2017/2018.

Untuk mengetahui kemampuan menghitung integral tak tentu dan tentu dari fungsi aljabar sederhana serta penerapannya dalam menghitung luas daerah di bawah kurva, maka dilakukan tes terhadap apa yang telah diajarkan atau disampaikan oleh guru kepada siswa tersebut, sedangkan siswa yang diberi tes harus dimotivasi agar berusaha untuk mencapai hasil yang sebaikbaiknya. Setelah diperoleh skor tes kemampuan pengetahuan siswa, skor tersebut dianalisis tingkat kemampuannya secara individu dan kemampuan secara keseluruhan siswa dari jumlah peserta tes.

Kemampuan siswa dalam menyelesaikan soal dilihat berdasarkan indikator yaitu menghitung integral tak tentu dari fungsi aljabar sederhana, menghitung hasil integral tentu dari fungsi aljabar sederhana, menghitung integral tak tentu dari fungsi aljabar dengan menggunakan teknik substitusi, menghitung hasil integral tentu dari fungsi aljabar dengan menggunakan teknik substitusi, menghitung luas daerah yang dibatasi oleh kurva dengan sumbu-x, dan menghitung luas daerah yang dibatasi oleh dua kurva.

Menentukan nilai siswa menggunakan rumus sebagai berikut:

$$
N=\frac{S}{S_{\text {maks }}} \times 100
$$

dimana $N, S$, dan $S_{\text {maks }}$, masing-masing menyatakan nilai, skor mentah yag diperoleh siswa, dan skor maksimum.

Kategori tingkat kemampuan siswa dilihat berdasarkan Tabel 1 berikut yang bersumber dari dokumen guru SMA Syaichona Cholil Samarinda.

Tabel 1. Kategori Tingkat Kemampuan Siswa

\begin{tabular}{|c|c|}
\hline Nilai & Kategori \\
\hline $90<N \leq 100$ & Sangat Baik \\
\hline $82<N \leq 90$ & Baik \\
\hline $75<N \leq 82$ & Cukup \\
\hline$N<75$ & Kurang \\
\hline
\end{tabular}

Untuk menentukan presentase jumlah siswa berdasarkan kemampuan, digunakan penilaian sebagai berikut

$$
p=\frac{f}{n} \times 100 \%
$$

dimana $p$ adalah besaran rata-rata (dalam persentase), $f$ adalah jumlah peserta tes yang termasuk masing-masing kategori (yaitu sangat baik, baik, cukup, dan kurang), dan $n$ adalah jumlah peserta tes.

\section{HASIL PENELITIAN DAN PEMBA- HASAN}

Hasil tes kemampuan secara keseluruhan untuk subjek penelitian sebanyak 47 siswa. Skor siswa yang diperoleh kemudian diolah menjadi persentase. Deskripsi data hasil tes kemampuan dari keseluruhan subjek penelitian sebanyak 47 siswa dapat dilihat pada Tabel 2 berikut.

Tabel 2. Deskripsi Data Hasil Tes Kemampuan Siswa Kelas XII IPS SMA Syaichona Cholil Samarinda Tahun Ajaran $2017 / 2018$.

\begin{tabular}{|c|c|c|}
\hline Rata-rata & Median & Modus \\
\hline 55,2 & 57,8 & 66,7 \\
\hline
\end{tabular}


Rata-rata hasil tes keseluruhan 55,2 dengan nilai yang paling banyak dimiliki siswa yaitu 66,7 yang menunjukkan bahwa kemampuan menghitung integral tak tentu dan tentu dari fungsi aljabar sederhana serta penerapannya dalam menghitung luas daerah di bawah kurva siswa kelas XII IPS SMA Syaichona Cholil Samarinda dalam kategori kurang.

Tabel 3 Distribusi Kemampuan Siswa Kelas XII IPS SMA Syaichona Cholil Samarinda Tahun Ajaran 2017/2018

\begin{tabular}{|c|c|c|}
\hline Kategori & Frekuensi & Persentase (\%) \\
\hline Sangat Baik & 1 & 2,13 \\
\hline Baik & 2 & 4,26 \\
\hline Cukup & 2 & 4,26 \\
\hline Kurang & 42 & 89,36 \\
\hline Jumlah & 47 & 100 \\
\hline
\end{tabular}

Dari Tabel 3 dapat dilihat bahwa kemampuan siswa kelas XII IPS SMA Syaichona Cholil Samarinda tahun ajaran 2017/2018 terdapat empat kategori yaitu sangat baik, baik, cukup, dan kurang. Sebanyak $89,36 \%$ siswa masih memiliki kemampuan menghitung integral tak tentu dan tentu dari fungsi aljabar sederhana serta penerapannya dalam menghitung luas daerah di bawah kurva pada kategori kurang.

Ketercapaian kemampuan dalam penelitian ini juga dilihat dari skor yang diperoleh siswa yang selanjutnya diolah menjadi persentase. Berdasarkan skor yang diperoleh siswa, maka dapat diketahui kemampuan menghitung integral tak tentu dan tentu dari fungsi aljabar sederhana serta penerapannya dalam menghitung luas daerah di bawah kurva berdasarkan indikator soal pada tes kemampuan. Indikator soal nomor 1 adalah menghitung integral tak tentu dari fungsi aljabar sederhana. Indikator soal nomor 2 adalah menghitung hasil integral tentu dari fungsi aljabar sederhana. Indikator soal nomor 3 adalah menghitung integral tak tentu dari fungsi aljabar dengan menggunakan teknik substitusi. Indikator soal nomor 4 adalah menghitung hasil integral tentu dari fungsi aljabar dengan menggunakan teknik substitusi. Indikator soal nomor 5 adalah menghitung luas daerah yang dibatasi oleh kurva dengan sumbu-x. Indikator soal nomor 6 adalah menghitung luas daerah yang dibatasi oleh dua kurva. Rata-rata kemampuan menyelesaikan soal berdasarkan indikator soal dapat dilihat pada Tabel 4 berikut.

Tabel 4 Distribusi Rata-Rata Kemampuan Siswa Kelas XII IPS SMA Syaichona Cholil Samarinda Tahun Ajaran 2017/2018 Berdasarkan Indikator Soal

\begin{tabular}{|c|c|l|}
\hline $\begin{array}{l}\text { Nomor } \\
\text { Soal }\end{array}$ & $\begin{array}{l}\text { Rata-rata } \\
\text { Kemampuan } \\
\text { Siswa }\end{array}$ & Kategori \\
\hline 1 & 49,36 & Kurang \\
\hline 2 & 58,30 & Kurang \\
\hline 3 & 88,51 & Baik \\
\hline 4 & 62,70 & Kurang \\
\hline 5 & 62,27 & Kurang \\
\hline 6 & 7,52 & Kurang \\
\hline
\end{tabular}


Selanjutnya, distribusi kemampuan siswa berdasarkan indikator setiap nomor soal dapat dilihat pada Tabel 5 berikut.

Tabel 5. Distribusi

Persentase

Kemampuan Siswa Berdasarkan Indikator Setiap Nomor.

\begin{tabular}{|l|c|c|c|c|c|c|}
\hline & \multicolumn{6}{|l|}{ Nomor Soal } \\
\hline Kategori & 1 & 2 & 3 & 4 & 5 & 6 \\
\hline $\begin{array}{l}\text { Sangat } \\
\text { Baik }\end{array}$ & 29,8 & 36,2 & 83,0 & 14,9 & 0 & 0 \\
\hline Baik & 0 & 6,4 & 0 & 0 & 0 & 0 \\
\hline Cukup & 0 & 0 & 0 & 2,1 & 59,6 & 4,3 \\
\hline Kurang & 70,2 & 57,4 & 17,0 & 83,0 & 40,4 & 95,7 \\
\hline
\end{tabular}

Berdasarkan Tabel 5, pada soal nomor 1 siswa diminta untuk menghitung integral tak tentu dari fungsi aljabar sederhana. Sebanyak 29,8\% siswa mampu menyelesaikan soal yang termasuk dalam kategori sangat baik, sedangkan sebanyak $70,2 \%$ siswa dikategorikan kurang. Siswa yang belum mampu menyelesaikan soal yaitu tidak teliti dalam proses pengintegralan, yaitu siswa tidak menuliskan variabel. Siswa juga salah menentukan hasil saat proses mengoperasikan yang melibatkan bilangan negatif dengan bilangan positif. Peneliti menduga penyebab kesalahan yang dilakukan siswa tersebut tidak dapat mengerjakan soal dengan benar adalah kekurangtelitian, kuurang memahamai cara penyelesaian, ataupun kurang latihan dalam mengerjakan soal-soal yang serupa. Berdasarkan indikator soal nomor 1, bahwa rata-rata kemampuan menghitung integral diketahui bahwa kemampuan siswa menghitung integral tak tentu dari fungsi aljabar sederhana termasuk kategori kurang.

Pada soal nomor 2 siswa diminta untuk menghitung hasil integral tentu dari fungsi aljabar sederhana. Sebanyak 42,6\% siswa mampu menyelesaikan soal, sedangkan sebanyak $57,4 \%$ siswa dengan kategori kurang. Siswa pada kategori baik dan sangat baik mampu menerapkan konsep integral dengan benar, serta dapat melakukan penjumlahan dan pengurangan bilangan bulat dengan baik dalam menyelesaikan soal dan memberikan jawaban yang benar. Sedangkan siswa yang belum mampu, siswa kurang mampu menggunakan konsep integral. Siswa tidak memperhatikan nilai batas sehingga salah dalam mensubstitusi batas integral dan juga soal tidak dijawab hingga selesai. Hal yang memungkinkan siswa tidak menyelesaikan soal karena siswa kurang paham menggunakan konsep yang akan digunakan dalam menyelesaikan soal, siswa tidak mengerti langkahlangkah penyelesaiannya, penguasaan materi prasyarat yang kurang, kurang latihan ataupun karena waktu pengerjaan yang tidak mencukupi. Berdasarkan indikator soal nomor 2, bahwa rata-rata kemampuan menghitung integral, diketahui bahwa kemampuan siswa termasuk kurang.

Pada soal nomor 3 siswa diminta untuk menghitung integral tak tentu dari fungsi aljabar dengan menggunakan teknik substitusi. Sebanyak $83 \%$ siswa mampu. Sedangkan $17 \%$ siswa dikategorikan kurang. Siswa yang berada pada kategori sangat baik siswa mampu menerapkan konsep integral

110 Kemampuan Menghitung Integral Tak Tentu Dan Tentu Dari Fungsi Aljabar Sederhana Serta Penerapannya Dalam Menghitung Luas Daerah Di Bawah Kurva Siswa Kelas XII IPS SMA Syaichona Cholil Samarinda Tahun Ajaran 2017/2018

Panca Kristiana - P.M. Labulan - Berahman 
menggunakan teknik substitusi dengan benar, serta dapat melakukan perkalian bilangan pecahan dengan sangat baik dalam menyelesaikan soal dan memberikan jawaban yang benar. Sedangkan siswa yang belum mampu menyelesaikan soal, siswa kurang teliti dalam memperhatikan nilai bilangan sehingga salah ketika menentukan . Siswa memahami cara menentukan integral tentu menggunakan teknik substitusi namun karena salah dalam menentukan maka menghasilkan jawaban yang salah, selain itu beberapa siswa hanya mampu menuliskan informasi yang didapat dari soal. Hal yang memungkinkan siswa tidak menyelesaikan soal karena siswa kurang paham menggunakan teknik substitusi yang akan digunakan dalam menyelesaikan soal, siswa tidak mengerti langkah-langkah penyelesaiannya, siswa sengaja tidak melanjutkan jawaban, ataupun karena waktu pengerjaan yang tidak mencukupi. Berdasarkan indikator soal nomor 3, bahwa rata-rata kemampuan menghitung integral diketahui bahwa kemampuan menghitung integral tak tentu dari fungsi aljabar dengan menggunakan teknik substitusi termasuk kategori baik

Pada soal nomor 4 siswa diminta untuk menghitung hasil integral tentu dari fungsi aljabar dengan menggunakan teknik substitusi. Sebanyak $17 \%$ siswa mampu menyelesaikan soal, sedangkan $83 \%$ siswa dikategorikan kurang. Siswa yang berada pada kategori sangat baik mampu menerapkan konsep integral dengan benar, serta dapat melakukan operasi bilangan pecahan dengan baik dalam menyelesaikan soal dan memberikan jawaban yang benar. Sedangkan siswa yang belum mampu menyelesaikan soal, siswa belum mampu menerapkan konsep integral menggunakan teknik substitusi dengan benar namun belum mampu menerapkan konsep integral tentu dengan benar, ketika proses pengintegralan bentuk integral tentu konstanta masih tetap ditulis. Batas integral tentu tidak ditulis ketika proses pengintegralan. Sehingga memberikan jawaban yang benar dengan langkah yang tidak tepat. Adapun beberapa siswa yang mengerjakan soal tidak sampai selesai. Hal yang memungkinkan siswa tidak menyelesaikan soal karena siswa kurang paham menggunakan rumus yang akan digunakan dalam menyelesaikan soal, siswa tidak mengerti langkah-langkah penyelesaiannya, ataupun karena waktu pengerjaan yang tidak mencukupi. Berdasarkan indikator soal nomor 4, bahwa rata-rata kemampuan menghitung hasil integral tentu dari fungsi aljabar dengan menggunakan teknik substitusi termasuk kategori kurang.

Pada soal nomor 5 siswa diminta untuk menghitung luas daerah yang dibatasi oleh kurva dengan sumbu-x. Sebanyak 59,6\% siswa mampu mengerjakan soal dengan kategori cukup. Sedangkan 40,4\% siswa dengan presentase dikategorikan kurang. Siswa yang berada pada kategori sangat baik siswa mampu menerapkan aturan integral tentu dengan baik dan benar serta dapat melakukan operasi perkalian dan pengurangan bilangan dengan baik dalam menyelesaikan soal. Namun siswa tidak menggambar sketsa yang tepat dari fungsi yang diberikan untuk mengetahui daerah 
yang akan dihitung luasnya. Siswa langsung menghitung luas daerah dengan mengintegralkan fungsi yang diberikan dan menjadikan nilai sebagai batas integral. Dilihat dari cara siswa menuliskan integral yang merupakan luas daerah diketahui bahwa siswa belum memahami langkahlangkah yang harus dilakukan untuk menghitung luas daerah di bawah kurva, sehingga memberikan jawaban yang benar dengan langkah yang kurang tepat. Sedangkan siswa yang belum mampu menyelesaikan soal, tidak menjawab soal nomor 5. Berdasarkan pengamatan peneliti siswa tidak menjawab soal karena siswa kurang paham menggunakan rumus yang akan digunakan dalam menyelesaikan soal, siswa tidak mengerti langkah-langkah penyelesaiannya karena kurang latihan mengerjakan soal yang serupa, siswa sengaja tidak mengerjakan soal, ataupun karena waktu pengerjaan yang tidak mencukupi. Berdasarkan indikator soal nomor 5, bahwa rata-rata kemampuan luas daerah yang dibatasi oleh kurva dengan sumbu-x termasuk kategori kurang.

Pada soal nomor 6 siswa diminta untuk menghitung integral tak tentu dari fungsi aljabar sederhana. Sebanyak 4,3\% siswa mampu mengerjakan soal dan sebanyak $95,7 \%$ siswa dikategorikan kurang. Siswa yang berada pada kategori baik Siswa dapat menentukan titik potong kedua kurva. peneliti melihat bahwa siswa menguasai cara menentukan penyelesaian dari suatu persamaan kuadrat. Siswa mampu menerapkan aturan integral tentu dengan baik dan benar serta dapat melakukan operasi perkalian dan pengurangan bilangan dengan baik dalam menyelesaikan soal Namun siswa tidak menggambar sketsa yang tepat dari fungsi yang diberikan untuk mengetahui daerah yang akan dihitung luasnya. Dilihat dari cara siswa menuliskan integral yang merupakan luas daerah diketahui bahwa siswa belum memahami langkahlangkah yang harus dilakukan untuk menghitung luas daerah yang dibatasi dua kurva,. Sedangkan beberapa siswa tidak menjawab sampai selesai dan ada siswa yang tidak menjawab sama sekali soal yang diberikan. Berdasarkan pengamatan peneliti siswa tidak menjawab soal karena siswa kurang paham rumus yang akan digunakan dalam menyelesaikan soal, siswa tidak mengerti langkah-langkah penyelesaiannya, penguasaan terhadap materi prasyarat yang kurang, kurang latihan, siswa sengaja tidak mengerjakan soal, ataupun karena waktu pengerjaan yang tidak mencukupi. Berdasarkan indikator soal nomor 6 , bahwa rata-rata kemampuan menghitung luas daerah yang dibatasi oleh dua kurva termasuk kategori kurang.

Dalam penelitian ini, Siswa dikatakan mampu jika siswa berada dalam kategori kemampuan cukup, baik dan sangat baik, sedangkan jika siswa berada pada kategori kurang maka siswa dikatakan tidak mampu. Hal ini karena nilai siswa yang berada pada kategori kurang berada dibawah 75, yang artinya siswa masih belum terampil menghitung dalam pengintegralan.

Dari hasil penelitian, secara keseluruhan terdapat 42 siswa masih belum mampu dalam menyelesaikan soal yang berkaitan dengan integral. Hal

112 Kemampuan Menghitung Integral Tak Tentu Dan Tentu Dari Fungsi Aljabar Sederhana Serta Penerapannya Dalam Menghitung Luas Daerah Di Bawah Kurva Siswa Kelas XII IPS SMA Syaichona Cholil Samarinda Tahun Ajaran 2017/2018

Panca Kristiana - P.M. Labulan - Berahman 
tersebut berarti bahwa kemampuan menghitung integral tak tentu dan tentu dari fungsi aljabar sederhana serta penerapannya dalam menghitung luas daerah di bawah kurva siswa kelas XII IPS SMA Syaichona Cholil Samarinda dalam kategori kurang.

\section{KESIMPULAN}

Berdasarkan hasil penelitian tentang kemampuan menghitung integral tak tentu dan tentu dari fungsi aljabar sederhana serta penerapannya dalam menghitung luas daerah di bawah kurva siswa kelas XII IPS SMA Syaichona Cholil Samarinda tahun ajaran 2017/2018 dapat disimpulkan, ahwa dari 47 siswa kelas XII IPS yang telah melakukan tes kemampuan diperoleh 1 siswa dengan persentase $2,13 \%$ pada kategori sangat baik, 2 siswa dengan persentase 4,26\% pada kategori baik, 2 siswa dengan persentase $4,26 \%$ pada kategori cukup, dan 42 siswa dengan persentase $89,36 \%$ pada kategori kurang..

\section{DAFTAR PUSTAKA}

Alwi, H. 2003. Kamus Besar Bahasa Indonesia. Jakarta: Balai Pustaka.

Aunurrahman. 2014. Belajar dan Pembelajaran. Bandung: Alfabeta.

Depdiknas. 2003. Kurikulum Berbasis Kompetensi Pendidikan Prasekolah, Dasar dan Menengah. Jakarta: Departemen Pendidikan Nasional.

Dimyanti dan Mudjiono. 2006. Belajar dan Pembelajaran. Jakarta: Rineka Cipta.

Dharma, A. 2016. Analisi Kemampuan Menyelesaikan Soal Cerita Pada
Siswa Kelas VI Tahun Pelajaran 2015/2016 Di SD Negeri I Banjar Bali. E-Journal PGSD Universtas Pendidikan Ganesha Jurusan PGSD Vol.4 No.1.

Hamalik, O. 2012. Proses Belajar Mengajar. Jakarta: PT. Bumi Aksara. .2001. Kurikulum dan Pembelajaran. Jakarta: PT. Bumi.

Jihad, A. 2013. Evaluasi Pembelajaran. Yogyakarta: Pressido.

Kunandar. 2013. Penilaian Autentik (Penilaian Hasil Belajar Peserta Didik Berdasarkan Kurikulum 2013). Jakarta: PT. Raja Grafindo Persada.

Munandar, S.C.U. 1994. Mengembangkan Bakat dan Kreatifitas Anak Sekolah. Jakarta: Gramedia.

Muslich, M. 2011. Penilaian Berbasis Kelas dan Kompetensi. Bandung: Refika Aditama.

Ramlah. 2017. Analisis Kesalahan Siswa Dalam Menyelesaikan Soal Penjumlahan dan Pengurangan Pecahan di Kelas VII SMPN Model

Terpadu Madani. Jurnal Ilmiah Pendidikan Matematika. Vol.1 No.1

Sanjaya, W. 2006. Strategi Pembelajaran Berorientasi Standar Proses Pendidikan. Jakarta: Prenada Media Group.

Slameto. 2003. Evaluasi Pendidikan. Jakarta: Bumi Aksara.

Solaikah, A.D.S.N dan Suroto. (2013). Identifikasi Kemampuan Siswa Dalam Menyelesaikan Soal Aritmatika Sosial Ditinjau Dari Perbedaan Kemampuan Matematika. Jurnal Pendidikan 
Matematika STKIP PGRI Sidoarjo. 1, (01), 97-106.

Subanji dan Nusantara, T. (2013). Karakteristik Kesalahan Berpikir Siswa Dalam Mengonstruksi Konsep Matematika. Jurnal Ilmu Pendidikan Universitas Negeri Malang. No.2.

Sudjana. 2011. Penilaian Hasil Proses Belajar Mengajar. Bandung. Remaja Rosdakarya.

Sutikno, S. 2013. Belajar dan Pembelajaran. Lombok: Holistica.

Thoha, M.C. 1991. Teknik Evaluasi Pendidikan. Jakarta: CV. Rajawali.

Umar, H. 2004. Metode Penelitian untuk Skripsi dan Tesis. Jakarta: Raja Grafindo Persada. 